\title{
LA ACCIÓN DE JACTANCIA: ESTADO DE LA CUESTIÓN Y PROPUESTA DE RECUPERACIÓN NORMATIVA DE UNA ACCIÓN PROCESAL CIVIL
}

\section{THE ACT OF BOASTING: STATE OF THE QUESTION AND PROPOSAL FOR THE LEGAL REGULATION OF CIVIL PROCEDURAL ACTIONS}

\author{
LISARDO GARCIA RODULFO*
}

Recibido: 08/06/2019

Aceptado: 23/07/2019

SUMARIO: I. Concepto y Antecedentes. II. Naturaleza Jurídica. III. Contenido. IV. Características de la acción y relaciones con otras figuras jurídicas. V. Conclusiones. VI. Bibliografía.

SUMMARY: I. Concept and Background. II. Legal nature. III. Content. IV. Characteristics of the action and relations with other legal figures. V. Conclusions. VI. Bibliography

Resumen. El presente artículo, de carácter interdisciplinar, tiene por objeto en primer lugar, analizar la procedencia, naturaleza, contenido y características de la acción de jactancia, haciendo especial referencia a su relación con figuras jurídicas afines y, en segundo lugar, pretende demostrar su utilidad, no solo por su aplicación jurisprudencial, sino por constituir una herramienta jurídica útil para este siglo XXI. En este sentido, se efectúa una propuesta de regulación de la acción, dentro de nuestra Ley de Enjuiciamiento Civil.

Palabras Clave: Jactancia, Partidas, Alfonso X

Abstract. This article, which has an interdisciplinary focus, attempts to first, analyze the origin, nature, content, and characteristics of the act of boasting, with special reference to its relationship to related legal forms, and second, demonstrate its usefulness, not only through its application in jurisprudence, but as a useful legal tool for the XXI century. In this sense, a proposal for the regulation of actions, is made in the context of our Code of Civil Procedure.

Key words. Boasting, Partidas, Alfonso X

* Abogado en los Colegios de Granada y Madrid. Doctorando lisardo@maatasesores.com. ORCID 00000001-9957-4159 


\section{CONCEPTO Y ANTECEDENTES}

Según el Diccionario de la Lengua Española, etimológicamente el vocablo jactancia deriva de la latina iactantia que significa alabanza propia, desordenada, y presuntuosa. Jactarse equivale a alardear, con fundamento o sin él, de las cualidades personales; exaltar la propia excelencia. En parecidos términos la define Rodrigo Fernández de Santaella al indicar que la jactancia se identifica con la alabanza vana con que uno se vanagloria ${ }^{1}$.

En el ámbito jurídico, la jactancia según Escriche: "Es la manifestación que uno hace de cosas que pueden causar a otro algún perjuicio o menoscabo en su estado personal o en su reputación”2.

Para Corbella la jactancia, en sentido jurídico consiste en "alabarse una persona de tener derecho contra otra"3. Con similares palabras, Malaver precisa que es "la ostentación pública por el jactancioso de una pretensión jurídica respecto a un tercero, atribuyéndose determinados derechos reales o creditorios o bien acciones en contra del mismo, ocasionando con ello perjuicios materiales y morales al verdadero titular del derecho discutido" ${ }^{4}$.

Para Prieto Castro, la acción de jactancia "es concedida al sujeto contra el que otro se vanagloria de poseer un derecho obligacional, real o de cualquier clase en perjuicio del mismo, produciéndole inseguridad y peligro en la esfera jurídica, económica y moral, y está dirigida a obtener la declaración del juez de que se condene al demandado al perpetuo silencio" 5 .

Juan de Hinojosa la entiende como "aquella que incumbe a la persona difamada por otra, para dirigirse al Juez a fin de que condene al difamador (jactancioso) a que, en el plazo que aquel le señale, formule la correspondiente demanda probando sus imputaciones, y si no lo hiciere o no las probare, sea condenado a perpetuo silencio" 6 .

Finalmente, Lluís y Navas la define como: "la facultad de un sujeto determinado respecto de otro que pretende tener un derecho frente a él para exigirle que acredite judicialmente su pretendido derecho"7.

De todo lo anterior se puede colegir que la acción de jactancia se insta contra una persona que alardea públicamente de tener un derecho contra otra, a fin de obligarla a establecer la realidad de sus alegatos, bajo pena de ser condenada a eterno o perpetuo silencio. Dicho de otro modo, la acción de jactancia aparece como aquella pretensión

\footnotetext{
${ }^{1}$ FERNÁNDEZ DE SANTAELLA, R. (1789) "Vocabularium: seu lexicon ecclesiasticum, latinohispanicum”, http://www.bibliotecavirtualdeandalucia.es/catalogo/es/consulta/registro.cmd?id=1000895 ${ }^{2}$ ESCRICHE, J. (1875) Diccionario razonado de legislación y jurisprudencia nueva edición reformada y considerablemente aumentada por don José Vicente y Caravantes y don León Galindo y de Vera, Imprenta de Eduardo Cuesta, Madrid, Tomo III p. 420.

${ }^{3}$ CORBELLA Y PASCUAL, A. (1910) Voz jactancia en Enciclopedia Jurídica Española. Seix. Tomo XIX Barcelona, p. 919.

${ }^{4}$ MALAVER, A. M. (1944), Acción de jactancia y acción declarativa: legislación, doctrina, jurisprudencia, Editorial Depalma, Buenos Aires, p.12.

${ }^{5}$ PRIETO-CASTRO FERRÁNDIZ, L. (1932), "La acción declarativa (un estudio de historia, doctrina y legislación procesales)”, Revista General de Legislación y Jurisprudencia, nº 161, Madrid, pp 181 y ss.

${ }^{6}$ DE HINOJOSA, J. (1948), “Alrededor de la acción de jactancia”, Revista de Derecho Privado. Editorial Reus. Madrid. Tomo XXXII, pp. 986-987.

${ }^{7}$ LLUÍS Y NAVAS, J. (2003), "Las acciones laborales declarativas y de jactancia”, Revista técnico laboral, nº 98, Madrid, p. 709.
} 
que coloca al demandado en el trance de promover su respectiva acción dentro de un breve término o de perder el derecho a accionar que pretenda tener contra el actor o demandante, guardando perpetuo silencio sobre el particular. Así, se puede calificar como una específica acción que busca el cese de la amenaza que pende sobre el derecho de otro, para evitar que pueda perpetuarse una situación de incertidumbre.

En referencia a los antecedentes de la acción de jactancia, los glosadores encontraron su fundamento en el Digesto, refiriéndose al caso de que uno difame a otro negándole su condición de ingenuo, en este caso, el candoroso podría acudir a la autoridad judicial pidiendo protección para que el juez dictara la necesaria resolución poniendo término a la inquietud y a la injuria. Es la conocida como ley diffamari o provocatio ex lege diffamari, regulada en la Ley V, del libro VII, título XIV del Codex justinianeo ${ }^{8}$.

La acción, en opinión de Sentís Melendo: "se extendió a reprimir las calumnias y las difamaciones a la reputación o a la condición social de alguno; y se llegó por analogía, a ejercitar a su amparo y bajo su forma, las acciones personales, y en particular, las relativas a créditos. Se hizo gran uso de la acción de jactancia por los estudiantes de Bolonia, cuando, terminados sus estudios, habían de abandonar la ciudad; unas veces se dirigía contra quien, verdaderamente, se había jactado de poseer contra ellos un crédito, y otras la demanda, representando una ficción, trataba exclusivamente de conseguir una sentencia que pudiera de manifiesto que contra el demandante no se había formulado o no había prosperado reclamación alguna"9.

En este mismo sentido, según De Castro, la actio iniuriarum se instaba junto a otras acciones ordinarias, en aquellos casos donde existía un evidente desprecio a la persona ${ }^{10}$.

Valabrègue pone de manifiesto el carácter meramente declarativo de los praejuditia; esto es de las sentencias derivadas de la acción diffamari al indicar: "Todo el mundo sabe cuál era, en Derecho Romano, el carácter de los praejudicia; y cuál era la finalidad a que tendían. Aquel cuyo estado había sido impugnado por terceros podía, si le parecía bien, esperar a ser atacado, para hacer valer sus derechos en justicia; incluso era lo más prudente por su parte. Pero podía también, si no quería permanecer mucho tiempo bajo el peso de imputaciones perjudiciales para su consideración adelantarse y

\footnotetext{
${ }^{8}$ Corpus Iuris Civilis (1837) Editio Sterotypa ex oficina caroli Tauchnitii cura D. Ioannis Ludovici Guilielmi Beck Tomo II p.250 De ingenuis et manumissis. "Diffamari statum ingenuorum, seu errore, seu malignitate quorumdam, periniquum est, praesertim cum afirmes, diu Praesidem unum atque alterum interpellatum a te vocitasse díversam partem, ut contradictionem faceret, si desensionibtis suis confideret. Unde constat, merito Rectorem provinciae commotum allegationibus tuis, sententiam dedisse, ne de caetero inquietudinem sustineres. Si igitur adhuc diversa pars perseverat in eadem obstinatione, aditus Praesses provinciae ab injuria temperare preacipet".

La traducción que realiza GARCIA DEL CORRAL I. (1988) El Codex, Editorial Lex Nova, Valladolid, refiere: De los ingenuos manumitidos. "Es muy inicuo que se difame el estado de los ingenuos por error o por maldad de alguno, mayormente afirmando tú, que habiéndose recurrido por ti hace ya mucho tiempo a uno y a otro presidente, llamaron a la parte contraria para que formulase su contradicción, si confiaba en sus medios de defensa. Por lo cual es evidente que, con razón, movido por tus alegaciones, el gobernador de la provincia dicto sentencia para que en lo sucesivo no soportares tal inquietud. Si, pues, todavía persevera la otra parte en la misma obstinación, el presidente de la provincia a quien recurra mandará que se abstenga de injuriarte".

${ }^{9}$ SENTÍS MELENDO, S. (1943), "El juicio de Jactancia (Ensayo de sistematización bibliográfica y jurisprudencial)", Revista de Derecho Procesal, Tomo II, Buenos Aires, p. 123.

${ }^{10}$ De CASTRO Y BRAVO, F. (1986), Compendio de Derecho Civil. Parte General II, Instituto de Estudios Políticos, Madrid, p. 35.
} 
hacer establecer en justicia su verdadero estado. La decisión que obtenía así no llevaba en sí misma condena alguna"11.

Asimismo, los glosadores encuentran también los orígenes en la ley XXVIII del libro I del título XLXVI del Digesto ${ }^{12}$, donde se autoriza al cofiador a provocar al acreedor para que inste su acción con objeto de que aquel pueda hacer valer la excepción de división de la acción ${ }^{13}$.

Es en la Edad Media cuando se encuentran los denominados juicios provocatenos, que Chiovenda califica como "una forma ruda y bárbara del proceso", orígenes más similares con la actual acción de jactancia. Son las llamadas "acciones de proclama” ${ }^{14}$.

El origen de la acción, según la profesora Tapia Fernández, se halla en la palabra "iacto", verbo iacio que significa vanagloriarse, jactarse o hacer alarde de una $\cos ^{15}$.

Algunos autores descubren en el derecho germánico el origen de estas acciones provocatorias para la tutela y protección de los intereses discutidos. Con esta procedencia germánica se muestra conforme Vincenzo Galante ${ }^{16}$. Por el contrario, Beceña y González remonta su estirpe no solo a las instituciones germanas sino también a las canónicas ${ }^{17}$. En este mismo sentido es Prieto Castro quien afirma que la "provocatio ad agendum" aparece en el "Espejo Sajón” como una manifestación asamblearia del pueblo ${ }^{18}$.

Para Juan de Hinojosa su abolengo se encuentra en la combinación del "remedium en lege diffamari, a que hace referencia el Codex, lib. 7, tít. 14, ley 5, con "la provocatio ad agendum característica del proceso germánico"19.

Así, Fraga Iribarne afirma: "Nos encontramos ya, en efecto ante la auténtica acción provocatoria, en sus dos famosas formas: la provocatio ex lege diffamari y la provocatio ex lege si contendat. Su característica común es la provocación a otra

\footnotetext{
${ }^{11}$ ERNEST VALABRÈGUE, M. (1888) "De la loi Diffamari, ou de l'action de jactancie, en droit romain et en droit français”. Revue de Legislatión et Jurisprudence, XXXVII, anné, nouvelle série, t. XVII París, pp. 18 y 19

${ }^{12}$ DIGESTO Título XLVI, Libro I, Ley XXVIII (De fideiussoribus et mandatoribus): "Si contendat fideiussor, ceteros solvendo esse; etiam exceptionen ei dandam, si non et illi solvendo sint”.

La Traducción de Álvaro D’ORS, A., HERNÁNDEZ TEJERO, F., FUENTESCA DIAZ, P., GARCÍA GARIDO M., y BURILLO, J. (1975) El Digesto de Justiniano, Editorial Aranzadi, Pamplona, refiere:

"Si un fiador sostiene que los otros fiadores son solventes, se le debe dar la excepción a no ser que también ellos sean solventes” La Traducción extraída de El Digesto de Justiniano de Álvaro D’Ors, Hernández Tejero, Fuenteseca Díaz, M. García Garrido y J. Burillo. Editorial Aranzadi, Pamplona 1975).

${ }^{13}$ BECEÑA Y GONZÁLEZ, F. (1928) Magistratura y Justicia. Notas para el estudio de los problemas fundamentales de la organización judicial, Victoriano Suárez, Madrid, p. 349.

${ }^{14}$ CHIOVENDA, G. (1933) “Azioni e sentenze di mero accertamento". Rivista di Diritto Processuale Civile, vol. 10. $1^{\text {a }}$ parte, p. 3

${ }^{15}$ TAPIA FERNÁNDEZ, I. (1984) "Las condenas no pecuniarias (Ejecución de sentencias de dar, hacer y no hacer)" Cuadernos de la Facultad de Derecho, nº 9, Universidad de las Islas Baleares, p. 187.

${ }^{16}$ GALANTE, V. (1910) Diritto processuale civile, Parte genérale, Editorial L. Álvaro, Nápoles, p. 230.

${ }^{17}$ BECEÑA Y GONZÁLEZ, (1928), p. 348, quien se basa en WETZELl, (1878), System des ordentlichen, pp. 97 a 106, coincide con VALABRÉGUE (1988), "De la loy dlffamari, ou de l'action de jactance, en Droit romain et en Droit français", trabajo publicado en Revue Critique de Législation et de Jurisprudence, año 37, nueva serie, t. 17, París.

${ }^{18}$ PRIETO-CASTRO FERRÁNDIZ, (1932), pp.181 y ss.

${ }^{19}$ DE HINOJOSA, (1948), p. 987.
} 
persona para que entable un proceso, en oposición excepcionalísima al principio "Nemo invictus agere cogatur" 20.

Sin embargo, otros autores aluden, con incierta base científica, a un elemento de raíces islámicas en la noción de jactancia fjar como autoexaltación del honor ${ }^{21}$, o tal vez del vocablo árabe mahya ${ }^{22}$.

Por lo aducido, los antecedentes de la acción provocatoria se encuentran tanto en el Derecho Romano, especialmente en el Codex y en el Digesto de Justiniano como en el texto germánico del "Sassen Speyghel” o Espejo Sajón, descartándose cualquier otro precedente.

\section{NATURALEZA JURÍDICA}

Respecto a la naturaleza de la acción existe en la doctrina una diversidad de opiniones. La polémica no es reciente, ya Rodrigo Suárez en sus Allegationes et consilia quaedam singularia sostiene que tanto el remedium ex lege si contendat como la ley diffamari admiten un carácter declarativo en la medida en que su objeto, es la declaración de un derecho presente, en aras a la seguridad jurídica; en este sentido, minimiza la condena de futuro toda vez que en el presente existe una relación jurídica ${ }^{23}$. Fraga Iribarne refuerza esta opinión al afirmar que: "En Rodrigo Suárez hay sobradísimos elementos doctrinales para construir la teoría de la acción puramente declarativa” ${ }^{24}$.

Con parecidos argumentos a los de Rodrigo Suárez converge Diego de Covarrubias en su obra Opera omnia, donde aborda la doctrina medieval respecto a la acción de jactancia refiriendo y admitiendo la opinión de Suárez en relación a su naturaleza meramente declarativa ${ }^{25}$.

Opinión contraria sostiene Luis de Molina y Morales, quien, pese a admitir la acción declarativa por los tribunales, refuta tal admisión reconociendo que la acción de jactancia recogida en Partidas presenta una interpretación extensiva: "En tales cosas ésta o en otras semejantes dellas”. En particular, respecto a los mayorazgos, es partidario de la acción de jactancia contra el que pretenda tener mejor derecho al mayorazgo ${ }^{26}$. Similar parecer sostiene Antonio Gómez en sus comentarios a las leyes de Toro donde dice: "El interdicto retinendae compete contra cualquier persona que diga ser poseedor de la misma cosa de que en realidad lo es el que lo intenta. Asimismo, contra el que no dexa usar libremente de la posesión de aquella, arando, sembrando, edificando, cogiendo

\footnotetext{
${ }^{20}$ FRAGA IRIBARNE, M. (1951), La acción meramente declarativa, Editorial Reus, Madrid, p 18.

21 "La acción de Jactancia”, Guías Jurídicas Wolters Kluver, en http://guiasjuridicas.wolterskluwer.es/. Si bien tras esta afirmación, no efectúa referencia a ningún autor. [consultado el 13 de marzo de 2019]

${ }^{22}$ Que significa bravuconería, jactancia, chulería origen para algunos del término mafia.

${ }^{23}$ SUÁREZ, R. (1588), "Excellentissimae allegationes et consilia quaedam singularia”. Editorial Diego Fernandez de Córdoba. Salamanca. Libro digitalizado por la Universidad Autónoma de Madrid de libre descarga en la página https://repositorio.uam.es/xmlui/handle/10486/2262 [consultado el 20 de diciembre de 2018].

${ }^{24}$ FRAGA IRIBARNE (1951) p. 31.

${ }^{25}$ DE COVARRUBIAS Y LEYVA, D. (1762), Opera omnia. Editado Genevae: sumptibus Fratres de Tournes, Libro digitalizado en la Biblioteca Virtual de Patrimonio Bibliográfico en https://bvpb.mcu.es/es/consulta/resultados_ocr.do?autor_numcontrol=\&materia_numcontrol=\&id=8743\& forma=ficha\&tipoResultados=BIB\&posicion=8. [consultado el 20 de diciembre de 2018].

${ }^{26}$ DE MOLINA Y MORALES, L. (1573), “De Hispanorum primogeniis”. Andreas de Angulo. Libro digitalizado en la web Singularis. Tesoros bibliográficos del consorcio madroño en http://www.singularis.es/?p=3268 [consultado el 27 de diciembre de 2018].
} 
frutos, ó de otro qualqüier modo impidiéndola. También contra el que por solas palabras ó jactancia perturba la posesión si se verificare que por este motivo el poseedor no encuentre arrendatario para la cosa: y por lo mismo basta al actor para obtener en el juicio de este interdicto, la negación de posesión que el reo formalice en la contextacion, aunque no haya precedido material perturbación de parte de éste”27. Asimismo, argumenta que no es admisible la acción declarativa en la medida que es inviable un procedimiento respecto a derechos futuros.

Antonio Xavier Pérez y López hace mención a la acción de jactancia al comentar el aforismo "Ut nemo invitus agere, vel acusare cogatur": "Teniendo cada uno facultad de disponer a su arbitrio de sus cosas y derechos en el fuero externo, siempre que no perjudique a otro, se sigue que a ninguno puede obligarse a poner demanda sobre sus intereses, según lo ordena la rúbrica de este título, y una ley del Rey no. Pero aquel que ya ha puesto la acusación no puede abandonarla, sino en los casos prevenidos en el artículo Abolición, ni tampoco el actor tiene facultad de: dexar la demanda después de contestada (...). De esa ley se ha introducido en nuestros Tribunales el remedio conocido con el nombre de Demanda de Jactancia, -bienfreqüente en la práctica, que no solo tiene uso quando la disfamacion recae sobre los casos decididos en ellas ; sino es quando alguno extrajudicialmente, vocifera tiene derecho a nuestros bienes o intereses, sobre la legitimidad y fundamento de esta sólida práctica forense, han disputado largamente nuestras regnícolas y ha habido alguno tan adicto literal del Derecho civil, que ha prorrumpido en amargas censuras contra nuestros jurisconsultos por haberla introducido" 28 .

En la segunda parte del siglo XIX se retoma la vieja polémica tras cuatrocientos años de olvido, así el reconocido jurista Ortiz de Zúñiga, al distinguir entre "acciones prejudiciales y perjudiciales”, refiere: “Acción perjudicial. Por regla general las decisiones que recaen en los negocios litigiosos sólo perjudican a los que en ellos han litigado; pero hay ciertos casos en que causan también perjuicio a otras personas $^{29}$, y por eso se llaman perjudiciales las acciones que en ellas se ejercitan. Así sucede, por ejemplo, cuando se trata del derecho de un hijo, para que se declare si alguno lo es o no de matrimonio, y sea que la cuestión se sostenga entre marido y mujer, ya entre el mismo hijo y el padre o la madre. Si, pues, F. pide que se declare ser hijo de N., no solo consigue obtener los derechos inherentes á la cualidad de tal hijo, sino además los de hermano, tío, etc., contra los otros descendientes del mismo N., a pesar de no haber litigado con ellos. Esta acción corresponde también a la clase de las denominadas dobles.

Acción prejudicial. Esta es diversa de la anterior, pues se ejercita en un juicio previo o preliminar, el cual sirve de base o antecedente para otro posterior. Así sucede, por ejemplo cuando se propone la acción para pedir la herencia, en el concepto de ser el que la reclama hijo del testador, caso en el cual es prejudicial o anterior la acción

\footnotetext{
${ }^{27}$ GÓMEZ, A. (1777), Compendio de los comentarios extendidos por el maestro Antonio Gomez a las ochenta y tres leyes de Toro, Imprenta y librería de Don Manuel Martin. Madrid. Biblioteca digital de Castilla y León. http://bibliotecadigital.jcyl.es/es/consulta/registro.cmd?id=7372 [consultado el 3 de enero de 2019].

28 PÉREZ Y LÓPEZ, A.X. (1796) Teatro de la legislación universal de España e Indias, por orden cronológico de sus cuerpos, y decisiones no recopiladas y alfabético de sus títulos y principales materias. Imprenta de Ramón Ruiz, Madrid, Tomo X, pp. 222 y ss.

${ }^{29}$ Hace referencia a la Ley XX, tít. XXII Partida Tercera. “Como el juyzio que es dado entre algunos non puede empecer a otri, fueras en cosas señaladas”.
} 
dirigida a que se declare dicha cualidad de hijo; así también, cuando uno reclama la herencia testamentaria y se duda de la validez del testamento, pues entonces el heredero abintestato debe usar de la acción preliminar para que se declare ser nulo este instrumento; y en otros muchos casos de igual naturaleza” ${ }^{30}$.

Valabrègue en 1888 pone de manifiesto el carácter de la acción como meramente declarativa de la lex diffamari, opinión ratificada por Chiovenda en 1933 en su monografía sobre l'azione nel sistema dei diritti.

Por el contrario, Toro Melo y Echevarría Reyes, sin entrar en la naturaleza de la acción, argumentan que la demanda de jactancia ha tenido y tiene escasísima aplicación, aduciendo que es uno de los pocos casos en que se puede obligar a otro a demandar ${ }^{31}$.

Parecer distinto sostiene Salvador de la Colina, quien afirma que no es una acción poco usada, como lo demuestran las sentencias de los tribunales y, además, es una acción útil y eficaz para definir situaciones dudosas y perjudiciales, recogiendo algunos casos, en los que, como jurista, interpuso la acción provocatoria ${ }^{32}$.

Maynar Barnolas sustenta que la acción de jactancia se utiliza en contadas ocasiones porque "en nuestra Patria no abundan los jactanciosos lo que me produce una gran satisfacción, o acaso porque la epidermis española sea poco sensible a las picaduras de la jactancia, lo que me causaría muy honda pena” ${ }^{33}$.

Prieto Castro califica categóricamente la acción de jactancia como una acción declarativa negativa. Asimismo, Barona Vilar, siguiendo a Prieto Castro afirma que la acción de jactancia se asimila a la acción meramente declarativa ${ }^{34}$.

Por el contrario Maynar Barnolas dice que la acción de jactancia jamás podría ser meramente declarativa, porque aspira a que se condene al que se jacta de un derecho, a que ejercite en el mismo pleito por reconvención, o en otro distinto, la acción de que se crea o se finge asistido, ya que, si no lo hace, no se jacte mas, ni pueda, pasado el plazo a que se le señaló, ejercitar aquella acción que se creía, o se fingía asistido $^{35}$.

Siguiendo el criterio jurisprudencial, por todas, la sentencia de 22 de septiembre de 1944, es acertado considerar que se está ante una acción provocatoria y de condena. No obstante, alguna jurisprudencia menor, ciertamente minoritaria, sostiene el carácter declarativo de la acción, como la sentencia de 18 de junio de 2002 de la Audiencia Provincial de Madrid que dice:

“TERCERO. - Caracterización de la acción de jactancia. A pesar de la denominación no podemos decir que sea algo distinto de las acciones declarativas. Nuestro sistema procesal no responde a las teorías romanistas de la acción que remite a un catálogo más o menos exhaustivo de acciones, entendidas como el derecho subjetivo en pie de guerra, de forma que a cada derecho subjetivo vulnerado le corresponda una

\footnotetext{
${ }^{30}$ ORTIZ DE ZÚÑIGA, M. (1870), Práctica general forense, Volumen I. Imprenta de Don José Rodríguez Calvario, Madrid pp. 343-344.

${ }^{31}$ TORO MELO, D. y ECHEVERRÍA Y REYES, A. (1902), Código de Procedimiento Civil anotado, Imprenta, litografía y encuadernación Barcelona. Santiago de Chile, p. 267.

${ }^{32}$ DE LA COLINA, S. (1915), Derecho y legislación procesal. Materia Civil y comercial, Librería Nacional, Buenos Aires, Tomo I, segunda edición, p. 300.

${ }^{33}$ MAYNAR BARNOLAS, M. (1944), "De mi clínica. Acción de Jactancia”. Revista General de Legislación y Jurisprudencia, Editorial Reus, Madrid, p. 414.

${ }^{34}$ BARONA VILAR, S. (1999), Tutela civil y penal de la publicidad, Editorial Tirant lo Blanch, Valencia, p. 222.

${ }^{35}$ MAYNAR BARNOLAS (1944), p. 426.
} 
acción precisa y determinada. Estamos ante un sistema en el que la naturaleza de la pretensión se define por el contenido del pronunciamiento que se pide, y en el que la denominación de la acción no pasa de ser un nomem iuris de mayor o menor fortuna, y cuya única ventaja es la identificación del fenómeno jurídico, pero sin que el nombre desnaturalice la esencia de la pretensión.

La acción de jactancia responde a las características de las pretensiones declarativas en su vertiente negativa, dotada además de un fuerte componente provocatorio, que de alguna manera fuerza a la inversión de la iniciativa del contradictorio, y cuya eficacia se agota en la mera declaración de la existencia o inexistencia del derecho pretendido... La provocación no es un dato que nos lleve a construirla como un tertius genus, susceptible de erigirse en categoría independiente dentro de la clasificación general de las pretensiones. El carácter provocatorio también se encuentra en todos aquellos procesos que comienzan por un simple escrito o solicitud sin caracteres de demandada, y en los que el demandado asume la iniciativa de la contradicción cuando se opone, y por esa razón nadie los clasifica de procesos jactanciosos. Como muestra baste la cita del proceso ejecutivo del art.1429 L.E.C. de 1881 en el que la verdadera demanda es la oposición del ejecutado, o el proceso de protección de los derechos reales del art.41 L.H.

El problema -continúa la sentencia- es de extensión y de compatibilidad. De extensión en cuanto bajo el esquema histórico de la acción de jactancia cabrían desde los supuestos de interdictos de retener la posesión, citado por Rodrigo, que sería una subespecie de acción de jactancia, hasta la reacción de los perseguidos por métodos poco usuales de cobro de morosos. De compatibilidad, en cuanto a saber si puede convivir con las pretensiones específicas de protección de los derechos fundamentales de la L.O.1/82 de 5 de mayo" ${ }^{36}$.

Sin embargo, Juan de Hinojosa afirma que "la acción de jactancia no puede confundirse con las acciones declarativas. En aquélla, el punto de partida es la difamación en amplio sentido (...), en ésta, es la incertidumbre acerca del alcance de un derecho que en previsión de dudas y contiendas se intenta sea fijado por los tribunales" 37 .

De la misma convicción es Calonge Matellanes: "La acción de jactancia tiene un mayor ámbito de aplicación que las meramente declarativas, ya que consiste en provocar al que se jacta de un derecho a que lo ejercite en el plazo que le asigne el juez; pasado el mismo deberá guardar perpetuo silencio. Incluso la acción de jactancia puede dar lugar a sentencias que lleven aparejadas medidas cautelares o ejecutivas que conduzcan a la impositio silentii (Medidas que jamás se dan en las acciones meramente

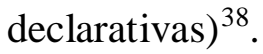

Partidario de la acción de condena es Fairén Guillén al afirmar: "Pero... a mi modesto entender, el error se halla en sustituir a una acción de condena, como era y es la de jactancia, por otra simplemente declarativa. Me parece que el justificado prestigio de las acciones declarativas negativas ha impedido seguir viendo la importancia -que

\footnotetext{
${ }^{36}$ CENDOJ (Centro de Documentación Judicial), Consejo General del Poder Judicial. http://www.poderjudicial.es/search/indexAN.jsp. Identificación Cendoj: 28079370012002104357

${ }^{37}$ DE HINOJOSA, (1948), p. 918.

${ }^{38}$ CALONGE MATELLANES, A. (2002), "La acción de Jactancia”, Estudios de derecho romano en memoria de Benito María Reimundo Yanes, Caja Duero, Asociación Iberoamericana de Derecho Romano, Salamanca, Tomo I, pp. 49-57.
} 
debe seguir siendo moderada, pero que no ha desaparecido- de las acciones provocatorias o de jactancia”39.

Sin embargo, la profesora Tapia Fernández indica que se puede advertir una naturaleza mixta en la medida en que se pretende, bien instar por el difamador como demandante, un nuevo proceso y si, por el contrario, no ejercitase la acción se estaría en presencia de una obligación de no hacer: condena consistente en el "eterno silencio" 40.

Lluís y Navas recoge las diferencias entre la acción provocatoria y la declarativa, ya que la primera es una excepción al principio nadie está obligado a demandar y, por el contrario, la declarativa es una acción directa. Asimismo, recoge la diferencia entre ambas acciones en cuanto a la posición procesal de las partes; al ostentar la jactancia un carácter de invertir la situación procesal, mientras que la declarativa no pretende tal alteración ${ }^{41}$.

A tales diferencias se puede añadir que, el artículo 521.1 de la Ley de Enjuiciamiento Civil establece respecto a las sentencias meramente declarativas y sentencias constitutivas que: "No se despachará ejecución de las sentencias meramente declarativas y constitutivas”, pudiéndose alegar, en caso de despacharse ejecución la nulidad radical del despacho de ejecución, al no contener la sentencia pronunciamiento de condena, a tenor de lo dispuesto en el artículo 559.3 de la referida norma procesal. Por el contrario, sí cabe la ejecución de una sentencia que admita una acción provocatoria en el caso de haberse incumplido el silencio perpetuo, por lo que ostenta efectos directamente ejecutivos ${ }^{42}$.

Lo realmente excepcional de esta acción estriba, en opinión de Calderón Cuadrado en que: "un ejercicio excepcional pero ininterrumpido de dicha acción, han hecho que se llegue doctrinal y jurisprudencialmente a conclusiones dispares sobre la admisibilidad de la jactancia en la actualidad"43.

Entre los pronunciamientos favorables destaca la sentencia del Tribunal Supremo, sala $1^{\text {a }}$, de 22 de septiembre de 1944, siendo ponente José Castán Tobeñas, que al respecto indica:

"CONSIDERANDO: Que nuestro antiguo Derecho, contenido en la ley cuarenta y seis, título II de la Partida III, recogiendo el remedium ex lege diffamari que la doctrina de los glosadores había elaborado con ingredientes de diversa procedencia, al enlazar algunos textos romanos, con el sentido de las provocationes ad agendum del proceso germánico, perfiló la llamada acción de jactancia, integrada por un doble elemento: a) el supuesto de hecho, constituido por la jactancia o difamación , que naturalmente ha de ir revestido de un cierto matiz de publicidad: quando alguno se va alabando, e diciendo contra otro, que es su siervo, o lo enfamando, diciendo del otro mal ante los omes; y b) el mecanismo y finalidad procesal, basados en el principio de la provocación a accionar; ça en tales cosas como estas, o en otras semejantes dellas, aquel

\footnotetext{
${ }^{39}$ FAIRÉN GUILLÉN, V. (1998), “La acción de jactancia como forma de tutela anticipada”, Revista de derecho procesal, año 1998, Número 2, p. 295.

${ }^{40}$ TAPIA FERNÁNDEZ, I. (1984), p. 192.

${ }^{41}$ LLUÍS Y NAVAS (2003), pp. 711 y 712.

42 Véase la sentencia 196 de la Sección quinta de la Audiencia Provincial de Zaragoza de 1 de abril de 2009. Ponente Antonio Luis Pastor Oliver que aborda una ejecución de sentencia por incumplimiento del perpetuo silencio relativa a la inscripción de la patente de la fregona. Id Cendoj: 50297370052009100090. ${ }^{43}$ CALDERÓN CUADRADO, M. P. (2015), Derechos, proceso y crisis de la justicia. Prohibido leer a Chiovenda, Publicaciones de la Real Academia Valenciana de Jurisprudencia y Legislación, Cuaderno $\mathrm{n}^{\circ}$ 85, Valencia, p. 28
} 
contra quien son dichas, puede yr al juez del logar, e pedir que constriña a aquel que las dixo, que le faga demanda sobre ellos en juyzio, e que las pruebe, o aquel faga otra enmienda, qual el judgador entendiere, que será guisada..." 44 .

Esta sentencia exige, para que la acción provocativa prospere, un doble requisito:

a) La acción de jactancia debe fundamentarse en la existencia de un acto de perturbación grave, cierto, conocido por el público, que afecte a la honorabilidad del contrario, difamándole.

b) El principio de la provocación, que se configura como una pretensión de tipo procesal y que pretende que el perturbador ejercite una acción judicial, o que, en su caso, lo pruebe en el plazo que le conceda el juez o "calle para siempre". Se trata, por tanto, de una acción que ostenta naturaleza personal, cautelar y de condena, quedando sin aplicación su previsión de escarmiento para aquellos casos en que, tras condena de silencio, se reprodujese jactancia; entonces deberán ser "escarmentados” de manera que "Otro ninguno non se atreva a enfamar, nin a decir mal de los omes tortizeramente" 45 .

En apoyo de esta tesis, la Sentencia del Tribunal Supremo de 20 de mayo de $1988{ }^{46}$ en la que claramente diferencia ambas acciones al referir, la inexistencia de una acción de jactancia en el asunto planteado, y si una acción meramente declarativa, toda vez que en el suplico de la demanda se fija claramente la pretensión del actor de declaración del derecho a tener acceso a un determinado terreno; es decir se establecen unas evidentes diferencias entre ambos tipos de acciones.

Sin embargo, la jurisprudencia no ha sido pacifica; así, la sentencia del Tribunal Supremo de 11 de mayo de 1995 se refiere a la acción de jactancia en su considerando tercero en el siguiente sentido:

“...Luego se puede afirmar que el acontecer procesal ha producido el resultado efectivo de que se mantenga la filiación; y por lo que respecta a la ratificación de la misma también pedida, carece de interés jurídico un pronunciamiento en tal sentido, cuando ya nadie pone en duda, ni combate en ninguna esfera, la declaración legal actualmente vigente; esa pretensión sería una especie de "acción de jactancia", figura histórica de dudosa vigencia, y desde luego no pedida con ese carácter, pues ni puede formar parte de la obligada y concreta absolución en las peticiones de la demanda, ni se incluyó en la reconvención que se formuló" 47 .

En palabras de Víctor Fairen Guillén: "La moderna y abusiva tendencia a anegar su campo [el de la acción de jactancia] por medios de las llamadas "acciones declarativas" (...) lleva a intentar sustituir a una acción de condena (...) en una simple declaración...”, y sintetizando el estado histórico de la cuestión reconoce acertada la postura del Tribunal Supremo al haber mantenido vigente la acción, evidenciando también la vigencia del debate ${ }^{48}$.

Como acertadamente indica Luis Gutiérrez Goñi: “Jurisprudencialmente, desde la época codificadora hasta la actualidad, llama en primer lugar la atención el número de pronunciamientos del Tribunal Supremo sobre la acción, que no siendo

\footnotetext{
${ }^{44}$ Repertorio de Jurisprudencia Aranzadi, (1944), Tomo XI, Pamplona, pp. 579-580.

${ }^{45}$ Las Siete Partidas Glosadas por el Licenciado Gregorio López, Boletín Oficial del Estado, Tomo II, Ley XLVI, p. 15

${ }^{46}$ CENDOJ, Consejo General del Poder Judicial, Id Cendoj 28079110011988100504.

${ }^{47}$ CENDOJ,. Consejo General del Poder Judicial, Id Cendoj 28079110011995103139.

${ }^{48}$ FAIRÉN GUILLÉN, V. (1988), "La «acción de jactancia» como forma de «tutela anticipada» en el proceso civil. Su futuro”, Revista de Derecho Procesal, Madrid, p. 288.
} 
excesivo tampoco está reducido a unos pocos, contando con alguno prácticamente cada una de las décadas desde la última del s. XIX hasta el presente (de lo que puede deducirse que la acción de jactancia sale tercamente de hibernación con cierta periódica frecuencia); en segundo lugar, también llama la atención la diversidad de cuestiones sobre las que el TS se pronuncia en relación con la acción, entre ellas -por lo que aquí interesa- varias de índole procesal, así como la reiteración en algunas de ellas, la forma en que a veces se trae a colación la acción y también alguna aparente incoherencia” ${ }^{49}$.

Para José Ignacio Fanjul Vicuña, "la jurisprudencia ha propiciado la aparición en la doctrina científica de dos teorías sobre la acción de jactancia: primera (basada en la STS de 10 de noviembre de 1986 ), de unidad de procedimientos, para la que la acción es defensiva y persigue la «declaración» judicial de que quien se jacta ostenta el derecho, o en caso contrario su condena a perpetuo silencio; segunda (basada en la STS de 20 de mayo de 1988 ), de duplicidad de procedimientos, para la que la acción es «provocatoria» y persigue que el juez fije plazo al que se jacta para que demande en defensa del derecho que pretende, o de no hacerlo calle para siempre" ${ }^{50}$.

De todo lo anterior, se puede colegir que existen dos visiones antagónicas acerca de la naturaleza de esta acción medieval. Es cierto que se aprecian similitudes entre la acción provocatoria y la meramente declarativa, en cuanto a su índole procesal, ambas ostentan un cariz personal, con excepción de la acción declarativa de dominio que claramente su naturaleza es de índole real ${ }^{51}$. Desde la perspectiva de su finalidad ambas acciones confluyen en configurar derechos particulares, si bien la acción de jactancia los garantiza y, por el contrario, la acción declarativa los determina. Sin embargo, la evidente finalidad de la acción declarativa estriba en la mera declaración judicial de existencia o inexistencia de una relación jurídica, sin que sea posible la ejecución de dicha sentencia; por el contrario, la acción de la ley XLVI no es meramente declarativa en la medida en que su finalidad es condenar al que se jacta, a ejercitar su acción o a desdecirse de lo dicho y, de no hacerlo, darlo por quito: "Aquel contra quien son dichas, puede yr al juez del logar, e pedir, que costriña a aquel que las dixo”, para que el perturbador ejercite una acción para probar las imputaciones hechas en descrédito del ofendido: "Que le faga demanda sobrellas en juyzio, e que las prueue, o que se desdiga dellas, o quel faga otra enmienda, qual el judgador entendiere, que será guisada", o por el contrario sino se retractare,: "E si por auentura fuesse rebelde, que non quisiese fazer su demanda, después que el judgador gelo mandasse, dezimos, que deue dar por quito al otro, para siempre”.

Por el contrario, la acción declarativa tiene por objeto obtener del juez un pronunciamiento sobre la existencia o inexistencia de un derecho subjetivo o relación jurídica. En consecuencia, serán pretensiones positivas, si lo que se insta es la declaración de existencia del derecho o de la relación jurídica y negativas, cuando lo que se persigue es la declaración de inexistencia.

Sin lugar a dudas, la complejidad de la acción de jactancia desborda lo meramente declarativo por varias razones. En primer lugar, se soslaya por la doctrina y

\footnotetext{
${ }^{49}$ GUTIÉRREZ GOÑI, L. (2002), "Algunas cuestiones procesales en los pronunciamientos judiciales sobre la acción de jactancia”, Revista Doctrinal Aranzadi Civil-Mercantil, n 15/2002, Cizur Menor.

${ }^{50}$ FANJUL VICUÑA, J. I. (1996), "La acción de jactancia. Estudios sobre Derecho Procesal”, Volumen I, Estudios de Derecho Procesal, Obra coordinada por Ignacio Díez-Picazo Giménez y Julián Martínez Simancas Sanchez, Editorial Central Hispano, SOPEC, Madrid, p. 154.

${ }^{51}$ Entre otros PUIG BRUTAU, J. (1994), Fundamentos de Derecho Civil, Editorial Bosch, Tomo III, Barcelona, p. 227.
} 
por la jurisprudencia que la demanda en ejercicio de la acción de jactancia, según la ley XLVI, no solo obliga a interponerse para probar la jactancia, sino que, con carácter alternativo, puede obligar al jactancioso a desdecirse de sus palabras, claro antecedente del derecho de rectificación o de la preceptiva acción en conciliación para obligar al sujeto que calumnia o injuria a retirar su ofensa, con carácter previo a la interposición en la esfera penal de una querella criminal. Es el derecho de retracto para invalidar o anular algo que se dijo con anterioridad, quien se retracta, se desdice o muestra su arrepentimiento por ciertas palabras que se pronunciaron. En segundo lugar, porque la acción en sí misma tiene una finalidad de condena para con el difamador, prohibiéndole para siempre su jactancia. Así, en tercer lugar, y como consecuencia de lo anterior, la condena que se pretende es el perpetuo silencio, la absoluta prohibición a que pueda promover o instar nuevamente la acción.

En palabras de Maynar Barnolas: "Si la acción de jactancia no existiera, habría que crearla, porque protege un derecho, sobre todo espiritual, que el órgano jurisdiccional tiene el deber de amparar" 52 .

Sea como fuere, la polémica persigue a la acción de jactancia. Ni la doctrina ni la jurisprudencia se ponen de acuerdo en su naturaleza jurídica, ni tampoco si la acción provocatoria debe continuar vigente o es una antigualla jurídica. Ni tan siquiera hay consenso en si está o no en vigor tras la aprobación de las leyes de enjuiciamiento civil y el Código Civil. Es una evidencia que la acción de jactancia despierta pasiones encontradas.

\section{CONTENIDO}

El 24 de julio de 1889 se publica en la Gaceta de Madrid el texto del Código Civil, que contempla en su artículo 1976 la disposición final del mismo, actualmente en vigor, que dice:

"Quedan derogados todos los cuerpos legales, usos y costumbres que constituyen el Derecho civil común en todas las materias que son objeto de este Código, y quedarán sin fuerza y vigor, así en su concepto de leyes directamente obligatorias, como en el de derecho supletorio. Esta disposición no es aplicable a las leyes que en este Código se declaran subsistentes”.

La discusión respecto a la aplicación de esta disposición final se ha centrado por la doctrina, en la alusión a "todas las materias que son objeto de este Código".

Como indica Francisco-Manuel Mariño Pardo: "Se contraponen dos posiciones; una primera entiende que, el derecho común anterior continuará vigente en aquellas materias que el Código no ha regulado o lo ha hecho de manera insuficiente. En este sentido se inclinan autores como Sánchez Román, Valverde y más modernamente Lacruz Berdejo. Frente a esta tesis, otra defiende el alcance general de la derogación del Código Civil respecto al derecho común anterior, con la excepción de las leyes declaradas subsistentes (como la Ley Hipotecaria, la del Notariado, la del Registro Civil, la de Aguas, la de Minas, la de Asociaciones). Se argumenta que la derogación lo es tanto en su condición de derecho directamente aplicable, como de derecho supletorio. La referencia a "las materias que son objeto de este Código" debe entenderse como materias de derecho civil, en cuanto el Código no afecta a normas situadas en otras ramas del derecho como el Código de Comercio o la Ley de Enjuiciamiento Civil. En

\footnotetext{
${ }^{52}$ MAYNAR BARNOLAS, (1944), p. 415.
} 
esta línea, que es mayoritaria, se sitúan autores como Castán, De Castro, Albaladejo, Espín, Díez-Picazo y Gullón entre otros” ${ }^{53}$.

Esta disposición derogatoria acabaría, en principio, con la vigencia de Partidas desde que se estableció como derecho supletorio en el Ordenamiento de Alcalá de 1348.

Por consiguiente, esta abolición se debería mantener respecto de la ley XLVI, título II (Del demandador e de las cosas que ha de catar, ante que ponga la demanda) de la Partida III (Que fabla de la justicia, e como se ha de facer ordenadamente en cada logar por palabra de juizio, e por obra de fecho, para desembargar los pleitos), que regula la acción de jactancia. La redacción de esta ley en la edición de Alfonso Díaz de Montalvo y en la de Gregorio López, son casi idénticas, no así la edición de la Real Academia de la Historia que tiene ligeras variaciones. La edición de Gregorio López dice así:

"Ley XLVI. Que ningún ome non deue ser constreñido que faga su demanda, si non quisiere, fueras ende en cosas señaladas. Constreñido no deue ser ningún ome que faga demanda a otro, más el de su voluntad la deue fazer si qusiere: fueras ende, en cosas señaladas, quel puedan los judgadores apremiar, segund derecho para fazerla. E la vna dellas es, quando alguno se va alabando, e diciendo contra otro, que es su sieruo, o lo enfamando, diciendo del otro mal ante los omes. Ca en tales cosas como estas, o en otros semjantes dellas, aquel contra quien son dichas, puede yr al juez del logar, e pedir, que costriña a aquel que las dixo, que le faga demanda sobrellas en juyzio, e que las prueue, o que se desdiga dellas, o quel faga otra enmienda, qual el judgador entendiere, que será guisada. E si por auentura fuesse rebelde, que non quisiese fazer su demanda, después que el judgador gelo mandasse, dezimos, que deue dar por quito al otro, para siempre: de manera, que aquel nin otro por el, non le pueda fazer demanda sobre tal razón como esta. E avn dezimos, que si dende en adelante se tornasse a decir del, aquel mal que ante auia dicho, que el judgador gelo deue escarmentar: de manera, que otro ninguno, non se atreua a enfamar, nin a decir mal de los omes tortizeramente".

La ley comienza proclamando el principio: "Nadie puede ser obligado a demandar” para, a continuación, establecer una excepción a este principio general: "Fueras ende, en cosas señaladas, quel puedan los judgadores apremiar, segund derecho para fazerla. E la vna dellas es...”.

El acto perturbador ha de ser grave, cierto, conocido por el público, que afecte a la honorabilidad del contrario, difamándole: "porque el decir de alguno que retiene alguna cosa contra conciencia, ya es hablar de él bastante mal o difamarle lo suficiente, para que pueda considerársele comprendido en esta ley" ${ }^{54}$.

Es también una acción provocatoria: "aquel contra quien son dichas, puede yr al juez del logar, e pedir, que costriña a aquel que las dixo”, o en la versión de la Real Academia de la Historia "bien se puede querellar aquel contra quien son dichas al juez del logar, et pedir que costringa á aquel que las dixo", para que el perturbador ejercite una acción, con el fin de probar las imputaciones hechas en descrédito del ofendido:

\footnotetext{
${ }^{53}$ MARIÑO PARDO, F. M. (2015), “Código Civil Parte General Tema 2 La codificación civil en España”, Temario de oposiciones a Notaria en https:/www.franciscomarinopardo.es/mis-temas/32-civilparte-general-temas-1-a-10?layout= [consultado el 2 de enero de 2019].

${ }^{54}$ SANPONTS Y BARBA, I. Y MARTI DE EIXALA, R.(1884), Siete Partidas del Rey Alfonso IX con las variantes de más interés y con la glosa del Licenciado Gregorio López, del Consejo Real de Indias de S.M., vertida al castellano y externamente adicionada con nuevas notas y comentarios y unas tablas sinópticas comparativas, sobre la legislación española antigua y moderna, hasta su actual estado, Imprenta de Antonio Bergnes, Tomo II, p. 62, Glosa 249.
} 
"Que le faga demanda sobrellas en juyzio, e que las prueue, o que se desdiga dellas, o quel faga otra enmienda, qual el judgador entendiere, que será guisada”, o por el contrario sino se retractare: "E si por auentura fuesse rebelde, que non quisiese fazer su demanda, después que el judgador gelo mandasse, dezimos, que deue dar por quito al otro, para siempre”.

En este punto, la glosa de Gregorio López se cuestiona si basta una sola notificación al perturbador para declararlo en rebeldía, refiriendo, en este sentido, que son necesarios dos requerimientos, como así lo indica Ángel Aret en su tratado Maleficiorum, con una excepción: en el caso que el perturbador, tras haber sido requerido por primera vez, hubiera manifestado expresamente que no quería interponer demanda ${ }^{55}$.

En la causa judicial estudiada por Justo García Sánchez de 1787, por la que, ante la jurisdicción canónica, Lorenzo Sánchez interpone acción de jactancia contra María Hernández por la divulgación del compromiso de boda, tras la preceptiva notificación del escrito de demanda, se instan por el actor tres escritos al vicario de Ciudad Rodrigo, juez eclesiástico que conoce de la demanda, para acusarla de rebeldía. Finalmente, se le notifica a la demandada auto donde se le confiere un último plazo de seis días: "que por equidad y en calidad de perentorios se la señalan, comparezca a responder a dicha demanda" 56 .

En los comentarios a las Partidas según la glosa de Gregorio López, editados en 1844 por Ignacio Sanponts y Barba, Ramón Martí de Eixala y José Ferra y Subirana, a este respecto indican: "tal vez sea aplicable al caso de que aquí se trata lo dispuesto en la ley 2, título 15, libro 11, de la Novísima Recopilación expresamente mandada observar por el artículo 48 del Reglamento provisional para la Administración de Justicia $^{57}$, sobre el no deber de acusarse mas que una sola rebeldía, para poder proceder contra el contumaz por vía de apremio; y entonces deberá decirse que, no proponiendo el difamador su demanda dentro del término que el juez le haya señalado en la providencia dada en méritos de juicio de jactancia, deberá sin necesidad de nueva providencia absolverse al difamado e imponerse al difamador silencio perpetuo en la cuestión que haya sido objeto de las jactancias" 58 .

Finalmente, la ley regula el supuesto de proseguir con el escarnio: "e avn dezimos, que si dende en adelante se tornasse a decir del, aquel mal que ante auia dicho,

\footnotetext{
${ }^{55}$ SANPONTS Y BARBA, I. Y MARTI DE EIXALA, R. (1884), pp. 63 y 64. Glosa 251 que dice: ¿Bastará, empero que se le haya mandado una sola vez? La Glosa de la authent. "de hoered et falc si quis autem nom impleus", en la palabra admonitus, pretende que son necesarios dos requerimientos para que pueda privarse al requerido de su derecho".

${ }^{56}$ GARCÍA SÁNCHEZ J. (2002), "La acción de jactancia. una institución fundada en la normativa romana postclásica, aplicada en la práctica procesal canónica hispana de la Edad Moderna”, Estudios jurídicos "in memoriam" del profesor Alfredo Calonge / coord. por Justo García Sánchez, Pelayo de la Rosa Díaz, Armando José Torrent Ruiz, p. 474.

${ }^{57}$ Aprobado por Real Decreto de 26 de septiembre de 1835, dice en su artículo 48: En los negocios civiles en que el juicio deba ser por escrito, se arreglarán puntualmente al orden de proceder establecido por las leyes del reino, teniendo muy presente lo prescrito en el art. 4 de este reglamento y para ello observarán y harán observar cualesquiera que sean las prácticas, o más bien corruptelas introducidas en contrario , las reglas siguientes: $1^{\text {a }}$ Que no admitan demanda que no tenga todos los requisitos prevenidos por las leyes I. y 4 i título 3 libro II de la Novísima Recopilación...” Reglamento Provisional para la Administración de Justicia en lo respectivo a la real Jurisdicción Ordinaria (1836) Imprenta de Santalo, Canalejas y Compañía. Córdoba, pp. 14-15.

${ }^{58}$ SANPONTS Y BARBA, I., MARTÍ DE EIXALA, R. y FERRA Y SUBIRANA, J., (1844), p. 64, Glosa 251.
} 
que el judgador gelo deue escarmentar: de manera, que otro ninguno, non se atreua a enfamar, nin a decir mal de los omes tortizeramente”.

\section{CARACTERISTICAS DE LA ACCIÓN Y RELACIONES CON OTRAS FIGURAS JURIDICAS}

XLVI:

Es preciso destacar las siguientes características fundamentales de la Ley

1.- Partidas no denomina la acción de jactancia como tal, si bien la glosa de Gregorio López -refiere en las notas de la 248 a la 252- en catorce ocasiones los términos: jactancias, demanda de jactancias, juicio de jactancias y jactado.

2.- La ley establece la posibilidad de revocar, de volver atrás, al indicar: "o que se desdiga dellas". Este derecho a dejar sin efecto lo dicho o de retracto, no ha sido estudiado ni por la doctrina ni por la jurisprudencia.

No es entendible este derecho a desdecirse sin abordar, siquiera de soslayo, la importancia del honor y de la palabra dada en Partidas: "La primera es de palabra [...]; e de palabra es, como su un ome denostalle a otro, o le diese bozes ante muchos faciendo escarnio del, o poniendo le algún nome malo, o diciendo empos de las muchas palabras atales, onde se tuuiese al otro por deshonrrado" 59 .

En la ley IV, del título XXI, Partida VII, al referirse a los tipos de penas, se contempla en sexto lugar la infamia, una pena inferior en grado a la muerte civil. Los infames eran personas inhábiles para honores y dignidades. Un grado inferior a la infamia es la denominación de "hombre de menos valer", minus valens. El hombre inferior a los demás para la vida judicial civil, que "no podía ser par de otros en lid, ni acusar, ni dar testimonio en juicio”. Caía el hombre en menor valer cuando había prometido pleito-homenaje y no lo cumplía o por desdecirse de lo dicho en juicio. Estas disminuciones de valía se reparaban difícilmente ${ }^{60}$.

La Real Academia define el vocablo retractación, -del latín traho, derivado de tracto- que significa revocar expresamente lo que se ha dicho, desdecirse de ello volver atrás de lo convenido, retirar la palabra.

El derecho a desdecirse que contempla la acción de jactancia, tiene una especial incidencia en el derecho indiano; así lo contempla Solórzano en su Política Indiana al referirse a los privilegios de los indios al poder retractarse de documentos, e incluso de las declaraciones, prestadas en juicio: "pueden venir, decir y alegar contra los instrumentos que hubieren presentado y contra las confesiones que sus abogados hubieren hecho en los libelos o peticiones y revocarlas no sólo in continenti, sino cada y cuando les convenga y pedir nueva prueba y presentar nuevos testigos después de hecha la publicación, y en segunda instancia, aunque sea sobre los mismos artículos o derechamente contrarios”61.

\footnotetext{
${ }^{59}$ Las Siete Partidas Glosadas por el Licenciado Gregorio López, Partida VII, título IX, ley I.

${ }^{60}$ Las Siete Partidas Glosadas por el Licenciado Gregorio López, Partida VII, título V, Ley I, II y III.

Ley I.- Que cosa es menos valer. Usan los omes dezir en España una palabra, que es valer menos. E menos valer es cosa, que el ome cae en ella, non es par de otro en Corte de Señor, nin en juyzio: e tiene grand daño a los que caen en tal yerro. Ca non pueden dende en adelante ser pares de otros en lid, nin fazer acusamiento, nin en testimonio, nin en las otras honrras, en que buenos omes deuen ser escogidos; assi como diximos en ante de los enfamados, en el título que fabla deellos.

${ }^{61}$ DE SOLÓRZANO PEREIRA, J. (1703), "Política Indiana”, Henrico y Cornelio Verdussen. Amberes. $\begin{array}{lllllll}\text { Libro } 2 & 2 & \text { capitulo } 28 & \text { número } & 25 & \text { Biblioteca } & \text { Digital }\end{array}$
} 
El derecho a desdecirse está estrechamente vinculado a los medios de comunicación desde la enmienda presentada por el diputado Delaure a la ley francesa de 1796 de prensa; esta proposición no admitida, pretendía la inclusión del derecho de rectificación. Posteriormente, en 1822, también en Francia, se aprueba una nueva ley de prensa, donde se contempla el derecho de rectificación en su artículo 11: "Los propietarios de todo diario o escrito periódico están obligados a insertar dentro de los tres días de la recepción o en el número más próximo, si éste no se publicase antes de la expiración de los tres días, la respuesta de toda persona nombrada o designada en el diario o escrito periódico, bajo pena de multa de cincuenta a quinientos francos, sin perjuicio de otras penas y daños o intereses a los que el artículo incriminado pudiera dar lugar. Esta inserción será gratuita y la respuesta podrá tener el doble de la extensión del artículo a que se refiera" 62 .

Tiempo después, se regula, también en Francia la ley de 29 de julio de 1881 donde se consagra el derecho de rectificación en términos muy parecidos a los existentes. Este texto legal sirvió de referencia para la aprobación en España de la Ley Gullón, Ley de Policía de Imprenta aprobada siendo presidente del Gobierno Práxedes Mateo Sagasta, el 26 de julio de 1883.

Tras la Guerra Civil, el derecho de rectificación y réplica, se regula en la derogada Ley de Prensa de $1966^{63}$ y en la vigente Ley Orgánica 2/1984 que establece una regulación unitaria de ambos derechos en su artículo 1 al indicar que el derecho de rectificación consiste en la facultad otorgada a toda persona natural o jurídica de rectificar la información difundida por cualquier medio de comunicación, de hechos que le aludan, que considere inexactos y cuya divulgación pueda causarles perjuicio. Este derecho se esgrime, en primer lugar, ante el medio de comunicación mediante escrito de rectificación, en el plazo de siete días desde que apareció la noticia, por el que el afectado considera que la misma es errónea. El medio de comunicación deberá otorgarle igual relevancia que la noticia primigenia. Transcurridos tres días desde la recepción de la rectificación sin que se publicase o se efectúe sin respetar el precepto legal, el afectado podrá acudir en siete días al juez de primera instancia en amparo del derecho de rectificación.

3.- La ley XLVI es un claro precedente de otras instituciones jurídicas que atentan contra el honor como la injuria o deshonra, dado que en el texto legal tiene cabida el obligar al difamador a que se desdiga de lo dicho, en clara alusión al vigente y preceptivo acto de conciliación a instar con carácter previo a la interposición de querella criminal por injuria o calumnia. Este acto de conciliación pretende, en primer lugar, el reconocimiento de las manifestaciones injuriosas y, en segundo lugar, aceptar que lo dicho es falso y carece de fundamento.

Se encuentran antecedentes del delito de injuria en la Ley de las XII Tablas que posteriormente evoluciona, al decir de Mommsen: "la injuria de las XII Tablas... se diferenciaba teóricamente de la iniuria regulada por el derecho de los tiempos

http://bibliotecadigital.aecid.es/bibliodig/es/consulta/registro.cmd?id=822. [consu8ltado el 20 de marzo de 2019].

${ }^{62}$ BALLESTER ELIEL, C, (1987), Derecho de Respuesta. Réplica, rectificación, Editorial Astrea, Buenos Aires.

${ }^{63}$ Ley de Prensa e Imprenta de 18 de marzo de 1966, conocida como Ley Fraga regulaba en su artículo 58 la réplica que era un derecho atribuido solo a particulares distinto al derecho de rectificación regulado en el artículo 62 que era potestad exclusiva de la Administración y autoridades. 
posteriores, en que la primera era la lesión corporal, cuyo autor pudiera ser responsable legalmente de ella, y la segunda era la ofensa causada dolosamente a la personalidad" 64 .

Sin considerar Partidas, el Fuero de Cuenca contiene la más amplia regulación del delito de injurias. En este sentido Serra Ruiz refiere: "Las injurias verbales o de ofensa directa al sentimiento espiritual del honor son más abundantes en el Fuero de Cuenca que en la legislación precedente, como corresponde a un cuerpo legal más progresivo. Es de advertir que, en algún caso (rúbrica XXI, cap. XII), el Fuero de Cuenca sigue el sistema de "numerus apertus" en el enunciado de las palabras o frases que son tenidas por injuriosas, no limitándolas a un catálogo cerrado de palabras, sino enunciando que pueden ser castigadas, además de las que se mencionan, otras que son semejantes: et alia que istis sunt simia"65.

El Fuero de Cuenca otorgado por Alfonso VIII en torno a 1190, sirvió de modelo a una amplia familia de fueros, como son los de: Sepúlveda, Zorita, Teruel, Usagre, Albarracín, Alcalá, Salamanca, Coria, Alba de Tormes, Plasencia, Béjar, Zorita de los Canes, Baeza y Úbeda. Todos ellos penalizan el delito de injuria por proferir expresiones como: puta, rozina o monaguera a la mujer y cornudo, invertido, leproso o hereje al hombre. Lo que también contemplan la mayor parte de los fueros referidos, y esto es lo relevante, es la posibilidad que se concede al injuriante de desdecirse de los denuestos proferidos, claro precedente del retracto regulado en la acción de jactancia y, en definitiva, de la actual conciliación entre partes, previa a la interposición de una querella criminal.

También se contempla la ofensa verbal injuriosa en la ley II del Fuero Real, al castigar: "a qualquier home que à otro denostare, è le dixere gafo, ò sodometico, ò cornudo, ò traydor, ò herege, o à mujer de su marido puta... é si dixere otros denuestos”66. El título IX de la séptima partida normativiza en veintitrés leyes el delito de injuria: "de las deshonrras quier sean fechas, o dichas a los biuos, o contra los muertos, e de los famosos libelos". Sin embargo, en este título no se recoge la posibilidad al injuriante de desdecirse.

Esta tradición de positivizar los delitos contra la honra tiene continuidad en nuestro primer Código Penal de 1822, concretamente en su artículo 699, al penalizar el delito de calumnia: “Artículo. 699. El que en discurso o acto público, en papel leído, o en conversación tenida abiertamente en sitio o reunión pública, o en concurrencia particular numerosa, calumnie a otro imputándole voluntariamente un hecho falso, de que si fuere cierto le podría resultar alguna deshonra, odiosidad o desprecio en la opinión común de sus conciudadanos, o algún otro perjuicio, sufrirá una reclusión de uno a seis años, y se retractará públicamente de la calumnia. Si la imputación falsa fuere de delito o culpa a que esté señalada pena por la ley, se impondrá al calumniador, además de la retractación pública, la mitad a las dos terceras partes de la misma pena que se impondría al calumniador si fuere cierta la imputación; sin que en ningún caso pueda bajar la pena del que calumnie en público de uno a seis años de reclusión. Téngase por concurrencia particular numerosa para el caso de este artículo toda aquella que pase de diez personas, además de las que habiten en la casa o sitio privado donde se verifique la concurrencia.”

\footnotetext{
${ }^{64}$ MOMMSEN, T. (1976), Derecho Penal Romano (Traducción del alemán por Dorado) Editorial Tennis, Bogotá, p. 485.

${ }^{65}$ SERRA RUIZ, R, (1969), Honor, honra e injuria en el derecho medieval español. Universidad de Murcia, p. 115.

${ }^{66}$ Fuero Real de Alfonso X El sabio (2018), Boletín Oficial del Estado, Libro IV, Título IV, ley II.
} 
Interesa resaltar de este artículo la obligación imperativa de retractación pública.

También se contempla la retractación para el delito de injuria diferenciando si ésta se comete en un ámbito público o privado; así, el artículo 707 refiere: "La pena de la injuria grave cometida públicamente de cualquiera de los modos expresados en el artículo 699, y fuera de los cuatro casos exceptuados en el 706, será castigada con la satisfacción pública, $y$ con una reclusión o prisión de cuatro meses a cinco años”. Por el contrario, si la injuria se cometió privadamente requiere una satisfacción privada, si la injuria se efectuó en este ámbito: “Artículo. 711. La injuria grave cometida privadamente contra alguno a presencia de otra u otras personas, será castigada con un arresto de un mes a un año, y con la satisfacción que el injuriador de al injuriado a presencia del juez y escribano, de los testigos del suceso, y de cuatro hombres buenos”.

La retractación llega hasta nuestro vigente Código Penal de 1995 y, a este respecto, se estipula en el artículo 214: "Si el acusado de calumnia o injuria reconociere ante la autoridad judicial la falsedad o falta de certeza de las imputaciones y se retractare de ellas, el Juez o Tribunal impondrá la pena inmediatamente inferior en grado y podrá dejar de imponer la pena de inhabilitación que establece el artículo anterior.

El Juez o tribunal ante quien se produjera el reconocimiento ordenará que se entregue testimonio de retractación al ofendido y, si éste lo solicita, ordenará su publicación en el mismo medio en que se vertió la calumnia o injuria, en espacio idéntico o similar a aquél en que se produjo su difusión y dentro del plazo que señale el Juez o Tribunal sentenciador”.

4.- La acción provocatoria también obliga a aquel que efectúa una afirmación que pueda ser considerada injuriosa, ofensiva o que conlleve una merma en su descrédito, a la prueba de la verdad, la denominada exceptio veritatis.

Aquí se halla también una evidente relación con el delito de injuria a la que históricamente ha estado vinculada la prueba de verdad. Así la ley I del título IX de la Partida VII, tras regular que es la deshonra nos dice: "Pero si aquel que dehonrrase a otro por tales palabras, o por otras semejantes dellas, las otorgarse, e quisiesse demostrar que es verdad aquel mal que le dixo del, non cae en pena ninguna, si lo prouasse. Esto es por dos razones. La primera es, porque dixo verdad. La segunda es, porque los fazedores del mal se recelen de lo fazer, por la afrenta, e por el escarnio que rescibiran del” ${ }^{\prime \prime}$.

Es interesante apreciar la simbiosis que Partidas efectúa entre la injuria latina con la deshonra hispana, institución de profunda raigambre en el derecho castellano; así el honor conforma un elemento estructurador del sistema feudal y también del sistema liberal burgués de clases sociales. La pérdida del honor, la deshonra, es la condena al ostracismo, la postergación más absoluta, la mayor humillación. En este sentido la prueba de verdad, de clara tradición medieval, también se vertebra como institución imprescindible en nuestra legislación vigente. Si bien el Código Penal de 1822, respecto al delito de calumnias regulado en el artículo 699, anteriormente transcrito, contempla que la prueba de verdad para el calumniador, no conlleva la absolución sino una reducción de su pena por un equivalente a un delito de injurias y respecto a éstas, en su artículo 704, hace inviable la exceptio veritatis al indicar: "Es injuria grave la que se

\footnotetext{
${ }^{67}$ Las Siete Partidas Glosadas por el Licenciado Gregorio López, tomo III, Partida VII, título IX, ley I.
} 
cometa contra alguno, ya anunciando o diciendo de él , o echándole en cara a presencia de otra u otras personas cualquier delito, culpa, vicio, mala acción o mala propiedad determinada , aunque sea cierto lo anunciado, dicho echado en cara , siempre que esto pueda causar al injuriado una responsabilidad criminal, o deshonrarle, envilecerle, desacreditarle o hacerle odioso, despreciable o sospechoso en la opinión común o más generalmente recibida entre las gentes del pueblo respectivo. En estas injurias, cuando se cometan espontáneamente y a sabiendas, se supondrá siempre la intención de injuriar"

El Código Penal de 1848 ya consagra la exceptio veritatis para el delito de calumnia y así ha llegado a nuestros días hasta el vigente artículo 207 de nuestro Código Penal: "El acusado por delito de calumnia quedará exento de toda pena probando el hecho criminal que hubiere imputado”. En idéntico sentido se pronuncia el artículo 210 para el delito de injurias: "El acusado de injuria quedará exento de responsabilidad probando la verdad de las imputaciones cuando estas se dirijan contra funcionarios públicos sobre hechos concernientes al ejercicio de sus cargos o referidos a la comisión de infracciones administrativas”.

5.- La ley XLVI no contempla explícitamente la condena al denominado "perpetuo silencio", solo refiere: "que deue dar por quito al otro para siempre”.

El diccionario de la Real Academia Española introduce por primera vez en su edición de 1817 la expresión perpetuo silencio, definiéndola como un vocablo que en términos jurídicos significaba: fórmula con que se prohíbe al actor que vuelva a deducir la acción o a instar sobre ella ${ }^{68}$.

Sin embargo, la glosa 251 de Gregorio López refiere: “y entonces deberá decirse que, no proponiendo el difamador su demanda dentro el término que el juez le haya señalado en la providencia dada en méritos de juicio de jactancias, deberá sin necesidad de nueva providencia absolverse al difamado e imponerse al difamador silencio perpetuo en la cuestión que haya sido objeto de las jactancias”69.

Como acertadamente refiere Doral García: "Pocas conductas pueden imponerse a una persona tan gravosas, con tanto rigor, y a su vez proporcionar a la contraparte una protección más enérgica, que reducir indefinidamente al silencio" ${ }^{70}$.

El profesor Manuel Osorio define el perpetuo silencio como: "Pronunciamiento judicial en ciertas causas, como las derivadas del ejercicio de la 'acción de jactancia', en que el juzgador impone al demandado la obligación de no reiterar sus infundadas pretensiones, declaración o actitud"71.

En palabras de María Eugenia Albornoz: "Plantear la perpetuidad del silencio me parece entonces una decisión dramática: se trata de poner un límite temporal artificial a un devenir que estaba siendo. Es instalar la ausencia y borrar la huella, es

\footnotetext{
${ }^{68}$ Diccionario usual de la Real Academia de la Lengua (1817), Madrid.

${ }^{69}$ SANPONTS Y BARBA, I., MARTÍ DE EIXALA, R. y FERRA Y SUBIRANA, J. (1844), pp. 63-64, Glosa 251.

${ }^{70}$ DORAL GARCÍA DE PAZOS, J.A. (2002), "La hibernada acción de jactancia y el problema del silencio”, Estudios jurídicos en homenaje al profesor Luis Díez-Picazo, coordinado por Antonio Cabanillas Sánchez, Semblanzas, Derecho Civil, Parte General, Volumen I, p. 514.

${ }^{71}$ OSORIO M. (2004), Diccionario de Ciencias Jurídicas, Políticas y Sociales, Editorial Heliasta, Buenos Aires, p. 715.
} 
anular la posibilidad de memoria de lo que está existiendo porque se congela voluntariamente su desarrollo con una clausura abrupta inventada"72.

Como se ha indicado, se utiliza el término quito que significa libre o exento; en detrimento del concepto silencio perpetuo. Ello implica, en opinión de Víctor Fairén que: "la introducción de esa sanción es ajena, ulterior (o incluso anterior) al introducirse en esa provocatio especial un elemento más propio de una "actio ad silentium imponi" 73 . Sin embargo Albornoz Vásquez es de la opinión que el silencio perpetuo puede ser asimilable a la expresión "destruir bullicios” que se indica en el prólogo de la séptima partida al indicar: queremos aquí demonstrar en esta Setena partida, de aquella justicia, que destruyendo tuerce por crudos escarmientos las contiendas e los bullicios que se levantan delos malos fechos, que se fazen a placer de la una parte, e a daño e a deshonra de la otra ${ }^{74}$.

6.- Algunas figuras jurídicas afines a "dar por quito al otro para siempre”. Hoy día se pueden encontrar derechos directamente relacionados con la "impositio silentii", como es el "the right to be let alone" o "derecho a que nos dejen en paz", expresión pronunciada por el juez norteamericano Colley en una sentencia de 1873 referida por Martínez Moscoso ${ }^{75}$.

Posteriormente se publicó en Boston, el 5 de diciembre de 1890 un artículo de Samuel D. Warren y Louis D. Brandeis en la revista Harvard Law Review, en el que estos autores norteamericanos pretendían establecer un límite jurídico que vedase las intromisiones de la prensa en la vida privada, reivindicando el derecho "a que nos dejen en $\mathrm{paz}^{\prime \prime 7}$.

Más recientemente, el derecho al olvido supone un nuevo replanteamiento del perpetuo silencio. Se recoge en la Sentencia del Tribunal de Justicia de la Unión Europea de 13 de mayo de 2014, conocido como el caso Mario Costeja ${ }^{77}$.

\footnotetext{
${ }^{72}$ ALBORNOZ VÁSQUEZ, M. E. (2007), El mandato del silencio perpetuo. Existencia, escritura y olvidos de conflictos cotidianos. Chile 1720-1840, Justicia Poder y sociedad: recorridos históricos Chile siglos XVIII-XXI, Editorial Universidad Diego Portales, Santiago de Chile, p. 17.

${ }^{73}$ FAIRÉN GUILLÉN, V, (1999), "La acción de jactancia y su pasado y futuro”, Anales de la Real Academia de Jurisprudencia y Legislación, $\mathrm{n}^{\circ}$ 29, Madrid, p. 143.

${ }^{74}$ ALBORNOZ VÁSQUEZ (2007), p. 21

${ }^{75}$ MARTÍNEZ MOSCOSO, A. (2009), La Libertad de expresión en la nueva sociedad de la información. Perspectivas y conflictos entre derechos, Fundación Carolina, Cuenca, (Ecuador), p. 117.

${ }^{76} \mathrm{El}$ artículo, con ciertas libertades en la traducción comenzaba diciendo que el individuo debería tener protección de su persona y sus propiedades es un principio tan antiguo como la ley, pero de vez en cuando es necesario definir de nuevo la naturaleza y el alcance de esa protección. Cambios políticos, sociales y económicos, suponen el reconocimiento de nuevos derechos, y la Ley, en su eterna juventud, debe crecer para satisfacer las nuevas demandas de la sociedad. Inicialmente la Ley dio remedio a la interferencia física con la vida y la propiedad privada. Más tarde se reconoció la naturaleza espiritual del hombre, de sus sentimientos y de su intelecto de modo que el derecho a la vida se convirtió en el derecho a disfrutar de la vida, - el derecho al olvido, a que te dejen en paz, asegura el ejercicio de los amplios privilegios civiles, y el término «propiedad «ha crecido hasta incluir toda forma de posesión - intangible, así como tangible.

${ }^{77}$ El asunto tiene su origen en la publicación de una subasta en el BOE y en el periódico La Vanguardia de un bien inmueble propiedad de Mario Costeja. Se instaba por no haber pagado a la Tesorería de la Seguridad Social varias cuotas de autónomos. El periódico La Vanguardia, digitaliza la hemeroteca y al buscar este señor su nombre en google aparecía siempre como primer y segundo resultado la subsodicha subasta. La deuda fue abonada previamente a la subasta. Mario Costeja habiendo trascurrido varios años y permaneciendo dicha información en el buscador decide actuar. Su abogado se pone en contacto con La Vanguardia, su respuesta es que era una publicación legal y que no eran responsables de la misma. El siguiente paso fue acudir al buscador Google toda vez que la acción del buscador perjudicaba a este
} 
La sentencia establece en cuanto al alcance de los derechos del interesado, que los buscadores deben establecer un procedimiento para atender las solicitudes de protección de derechos, ponderando caso por caso los mismos (plasmación del artículo 12 de la Directiva del 95 respecto al derecho de oposición). En la sentencia se indican cuatro requisitos para ponderar la información:

- Atendiendo a la naturaleza de la información, si es sensible o no.

- Atendiendo a la naturaleza del tiramiento si es un blog o boletín oficial.

- Atendiendo a si la persona tiene el carácter de pública o no.

- Por último, la exactitud, actualidad e idoneidad de la información.

La relación entre ambas instituciones es evidente. Mientras que el "tenerlo como quito" obliga a no proferir expresión alguna por parte del difamador, el derecho al olvido es un derecho a suprimir algo escrito o recogido en los buscadores de internet y hace referencia al derecho a impedir la difusión de información personal a través de este medio cuando su publicación no cumple los requisitos de adecuación y pertinencia previstos en la normativa. En concreto, incluye el derecho a limitar la difusión universal e indiscriminada de datos personales en los buscadores generales cuando la información es obsoleta o ya no tiene relevancia ni interés público, aunque la publicación original sea legítima, en el caso de boletines oficiales o informaciones amparadas por las libertades de expresión o de información.

Recientemente el derecho al olvido ha sido objeto de regulación por el Reglamento (UE) 2016/679 del Parlamento Europeo y del Consejo, de 27 de abril de 2016, relativo a la protección de las personas físicas en lo que respecta al tratamiento de datos personales y a la libre circulación de estos datos, concretamente en su artículo 17 lo regula con la denominación derecho a la supresión al indicar:

"1. El interesado tendrá derecho a obtener sin dilación indebida del responsable del tratamiento la supresión de los datos personales que le conciernan, el cual estará obligado a suprimir sin dilación indebida...”

Este derecho al olvido se regula en parecidos términos por la Ley Orgánica 3/2018, de 5 de diciembre, de Protección de Datos Personales y garantía de los derechos digitales, concretamente en su artículo 15 con la denominación derecho de supresión. Refiere:

Artículo 15. Derecho de supresión. 1. El derecho de supresión se ejercerá de acuerdo con lo establecido en el artículo 17 del Reglamento (UE) 2016/679.

2. Cuando la supresión derive del ejercicio del derecho de oposición con arreglo al artículo 21.2 del Reglamento (UE) 2016/679, el responsable podrá conservar los datos identificativos del afectado necesarios con el fin de impedir tratamientos futuros para fines de mercadotecnia directa.

Señor. Escriben una carta a Google España y su respuesta es que no tienen nada que ver con el buscador que éste lo administraba Google EEUU y que ejerciten esas acciones en EEUU. A continuación inician un proceso de tutela de derechos ante la Agencia Española de Protección de Datos quien resuelve que la publicación de la Vanguardia era lícita y que la acción del buscador se consideraba tratamiento de datos de carácter personal y que el hecho que el motor de búsqueda en España generase publicidad y por ende negocio, consideró que era crucial para la vida del buscador y pedía a Google España e Internacional para que retirase dicha información de su buscador. La Audiencia Nacional formula una serie de cuestiones prejudiciales que son la base de la Sentencia del TJUE. 


\section{CONCLUSIONES}

Constituye el objeto principal de este trabajo el análisis de una institución regulada en la Partida III, del título II ley XLVI, la denominada acción de jactancia, hoy día en vigor, a pesar de las disposiciones derogatorias de los códigos de finales del XIX, gracias a que la jurisprudencia del Tribunal Supremo le ha otorgado validez en la mayoría de sus sentencias. La actualidad de la acción provocatoria constituye un hecho excepcional sin parangón en nuestro derecho.

A lo largo de este artículo se han analizado los antecedentes de la acción tanto en el Corpus Iuris como en el derecho germánico; la controversia respecto a su naturaleza jurídica, donde prima su vertiente provocatoria, respecto de la mero declarativa o mixta. Se han señalado igualmente las divergencias doctrinales $\mathrm{y}$ jurisprudenciales respecto de considerar la acción como una antigualla jurídica o con una vigencia que, con el trascurso del tiempo, se hace más tenue. Sea como fuere, el Tribunal Supremo ha renunciado a efectuar una interpretación histórica a tenor de lo dispuesto en el artículo 3.1 del Código Civil, al señalar que las normas también se interpretan en relación con los antecedentes históricos y legislativos (razón de su débil vigencia). A este respecto, se echa en falta una interpretación histórica de la acción, conocer el porqué de su regulación, los antecedentes en los que se inspiró, tal y como regulan las Compilaciones Forales que, en el caso de la acción de jactancia, se echa en falta.

No obstante, hay razones fundadas para sostener que la aplicación de la acción provocatoria por nuestro Tribunal Supremo no responde a una añoranza histórica sino a que la acción puede ser aún útil, después de más de 750 años. Así, se concluye este trabajo, por una apuesta clara por la vigencia de la acción y su necesaria regulación normativa que excluya cualquier atisbo de duda sobre su puesta en valor. Se propone un proyecto de ley que contemple su regulación dentro de la Ley de Enjuiciamiento Civil, no ya por una mera añoranza del pasado, sino porque aún la acción puede dar respuesta a diferentes supuestos de hecho muy actuales, tal y como se indicará en la exposición de motivos, a título meramente enunciativo: sustituir al obsoleto derecho de rectificación, que no puede dar respuesta al más importante medio de comunicación que hoy día supone internet y la preocupante proliferación de las "fake news" o noticas falsas, la acción puede ser una herramienta útil contra ficheros de morosos o contra las injurias leves o vejaciones injustas despenalizadas recientemente.

A manera de Exposición de motivos.

\section{I}

La ley 1/2000, de 7 de enero, de Enjuiciamiento Civil, aspira a profundizar en una necesaria aproximación de nuestra Administración de Justicia con el justiciable. Para ello, intenta ahondar en el principio de tutela judicial efectiva en un doble sentido, de una parte, insistiendo en unas garantías procesales plenas y, de otra parte, en ir acortando los tiempos de respuesta a las demandas del ciudadano. Para la plasmación de estos objetivos, se indicaba en la exposición de motivos de la ley rituaria, que se descartaban las reformas miméticas traídas del derecho comparado, reconociendo el valor histórico y cultural de nuestra ley de Enjuiciamiento Civil de 1881 y de todo nuestro acervo histórico jurídico, complementado por la ingente jurisprudencia y doctrina, siempre presta a integrar, interpretar y señalar carencias de nuestro ordenamiento jurídico. Así, la práctica judicial, debe de encontrar una respuesta jurídica 
ante un problema social muy extendido hoy día, como es la deshonra o la difamación en un sentido amplio.

\section{II}

Las Siete Partidas de Alfonso X el Sabio constituyen un verdadero código legal, el de mayor amplitud y trascendencia en la historia de las leyes de nuestro país, que estuvo en vigor desde la Edad Media hasta la Codificación y que tanto ha influido en el derecho de los países latinoamericanos. Su vigencia como derecho supletorio se remonta a las Cortes de Alcalá de Henares de 1348 a propuesta del rey Alfonso XI.

La plena vigencia de la ley XLVI del título II de la Partida III del códice alfonsí, elaborado hace más de 750 años, responde a una necesidad social: la de preservar la honra, obligando al que alardea a que inste acción en reclamación de su acusación jactanciosa. En este sentido, la jurisprudencia de nuestro Tribunal Supremo ha venido admitiendo la plena vigencia en nuestro ordenamiento de la acción de jactancia. Esta eficacia, no ha estado exenta de polémica doctrinal, principalmente se ha incidido en su artificiosa validez, como consecuencia de la entrada en vigor, en el siglo XIX, de las disposiciones derogatorias del Código Civil y de la Ley de Enjuiciamiento Civil. Asimismo, no ha estado exenta de controversia por la doctrina su naturaleza jurídica, en concreto, respecto a si la acción de jactancia es una acción meramente declarativa, una acción provocatoria o, por el contrario, su naturaleza es mixta.

\section{III}

La acción de jactancia es una pretensión cuyo objeto es obligar a quien, por actos, palabras o mero silencio, pone en duda la existencia del derecho ajeno, a ejercitar en plazo determinado aquellas acciones de que se crea asistido o, de no hacerlo, mantener perpetuo silencio en cuanto a aquel. Se trata, de una acción dirigida contra quien presume de ostentar un derecho frente al actor y pone en controversia el derecho de este. Así, como señala la sentencia del Tribunal Supremo de 22 de septiembre de 1944, la acción de jactancia está integrada por dos elementos: a) el supuesto de hecho constituido por la jactancia o difamación; b) el mecanismo o finalidad procesal basados en el principio de la provocación a accionar. El presupuesto de la acción consiste, por tanto, en alabarse una persona de tener un derecho contra otra, de manera que el perjudicado pueda obligar al jactancioso a que presente la demanda de su pretendido derecho en el término que se le fije y que, de no hacerlo, se le imponga "impositio silentii”. De ese modo, el derecho del cual se debe jactar el demandado es un derecho sobre el actor o, al menos, que le afecte tan directamente que pueda verse afectado en su honra o fama.

\section{IV}

Si bien su vigencia es incuestionable, el tratamiento otorgado por la Jurisprudencia ha ido constriñendo la acción a casos muy concretos, haciéndose necesario una regulación que delimite y precise su aplicación, amparando en un sentido amplio la honra de las personas físicas y jurídicas. En este sentido, la acción de jactancia podría dar respuesta, en primer lugar, al denominado derecho de rectificación, regulado por la Ley Orgánica 2/1984, de 26 de marzo, que ha quedado obsoleto, en la medida en que en la aparición de internet, hoy día el más importante medio de comunicación está condenando al ostracismo el ejercicio de este derecho, en segundo lugar, y muy relacionado con lo anterior, la preocupante dimensión que en las redes 
sociales está alcanzando las denominadas "fake news" o noticas falsas que están constituyendo un verdadero problema social. En tercer lugar, la presunción de veracidad de los denominados ficheros de morosos, así como la falta de control respecto de las cesiones de créditos, muchos de ellos ya prescritos, a terceras empresas que, continuamente realizan bancos, operadores de telefonía, eléctricas etc, que atosigan a llamadas, cartas y todo tipo de misivas, reclamando a los consumidores y usuarios unas cantidades de difícil acreditación, o finalmente, sin ánimo de ser exhaustivo, las consecuencias de la despenalización de las faltas realizada por la Ley Orgánica 1/2015 de 30 de marzo, concretamente las injurias leves o vejaciones injustas reguladas en el artículo 620 del Código Penal, siempre y cuando estén fuera del ámbito de convivencia familiar. Los supuestos de hecho mencionados pueden tener en la acción de jactancia un eficaz instrumento para no depositar en el deshonrado el deber de rectificar, o se interpone demanda o, en caso contrario, que se condene la deuda o jactancia al olvido, una forma actual de la "impositio silentii".

\section{V}

La acción de jactancia se regula con la introducción de un Capítulo III y en siete artículos como un procedimiento especial junto al proceso monitorio y cambiario, intentando clarificar las respuestas a las interrogantes que, con relevancia jurídica, han abordado la jurisprudencia y la doctrina respecto a la acción provocatoria; preservando la perspectiva histórica de incalculable valor $\mathrm{y}$, finalmente, instaurando un procedimiento especial rápido y eficaz que concluya bien con la interposición de un proceso declarativo, bien con el derecho al olvido de la perturbación jactanciosa. Se finaliza con una disposición derogatoria respecto a la ley XLVI del título II de la Partida III.

Artículo único. Modificación de la Ley 1/2000, de 7 de enero, de Enjuiciamiento Civil.

La Ley 1/2000, de 7 de enero, de Enjuiciamiento Civil, queda modificada como sigue:

Uno. Se modifica la denominación del título III del libro IV, De los procesos especiales que se denomina "título III.- De los procesos monitorio, cambiario y de la acción de jactancia”.

Dos.- Se añade al Título III del libro IV el Capítulo III.- De la acción de jactancia, que incluye siete nuevos artículos.

Artículo 828.- Casos en que procede.

1.- Podrá interponerse la acción de jactancia contra toda persona en la que concurra alguna de las siguientes circunstancias:

$1^{\circ}$ Que se hubiere atribuido, fuera de un procedimiento judicial, derechos propios sobre los bienes que constituyen el patrimonio del demandante, o afirme ser su acreedor.

$2^{\circ}$ Que alguien atribuya al demandante acciones y omisiones que, de ser ciertas, fueran constitutivas de delito leve o sanción administrativa.

$3^{\circ}$ Que el demandado se atribuya algún derecho que impida el ejercicio de facultades legales al actor, o niegue cualquier derecho o deber relacionado con su estado civil.

2.- En todo caso, la jactancia ha de ser grave y efectuada con publicidad, esto es, cuando se propague por medio de imprenta, radio, televisión, internet, redes sociales, registros de morosidad o por cualquier otro medio de eficacia semejante. 
3.- La interposición de la acción de jactancia no enerva ni limita cualquier otra acción legítima que pudiera interponer el demandante.

Artículo 829.- Competencia

Será competente para conocer la acción de jactancia el Juzgado de Primera Instancia del domicilio del demandado. Siendo de aplicación lo dispuesto en el artículo 813 respecto a la competencia del proceso monitorio.

Artículo 830.- Iniciación. Demanda y Requerimiento

1.-La acción de jactancia comenzará mediante demanda, firmada por abogado y procurador, en la que se indicarán la identidad y domicilio del actor, el domicilio o lugar en el que pueda ser hallado el demandado, la relación de hechos graves y realizados con publicidad, motivo de la interposición de la acción y cuándo y cómo ha tenido conocimiento de los mismos; acompañándose a la demanda los documentos que acrediten dichos hechos. Finalmente, se instará la petición para que el jactancioso afirme o niegue la exactitud de los hechos o se desdiga de ellos.

2.- El letrado de la Administración de Justicia admitirá en su caso, por medio de Decreto la demanda y, requerirá al demandado para que en el plazo de 10 días, comparezca en el procedimiento y manifieste por escrito la veracidad de lo esgrimido, lo niegue o, por el contrario, se desdiga de lo dicho.

3.- Si el demandado no compareciese, nada manifestase sobre los hechos o reconociese la verdad de los mismos, el juez mediante auto le requerirá para que en el plazo de veinte días interponga demanda mediante el juicio que corresponda, acreditando su interposición en el presente procedimiento.

4.- $\mathrm{Si}$, por el contrario, el demandado se desdice de lo dicho, el tribunal dictará sentencia sin más trámite.

Artículo 831.- Efectos de la falta de interposición de la demanda.

Cuando el demandado no hubiese presentado la demanda en el plazo establecido quedarán las actuaciones pendientes para dictar sentencia.

Artículo 832.- Efectos de la presentación de la demanda.

Cuando el demandado acredite la presentación de la demanda, el letrado de la Administración de Justicia acordará, previa notificación a las partes, el archivo de las actuaciones.

Artículo 833.- Sentencia y efectos.

En el plazo de diez días, el tribunal dictará sentencia donde resolverá sobre la veracidad de lo aducido en la demanda, acordando, en su caso, la retirada de las mismas del medio donde ostenta publicidad, y condenando al demandado, si así lo estimare, a guardar perpetuo silencio respecto a dichas manifestaciones objeto del presente procedimiento.

Artículo 834.- Prescripción de la acción.

La acción de jactancia no podrá interponerse trascurridos más de seis meses desde que tuvieron lugar los hechos o dichos que lo motivaron o, alternativamente, desde que el demandante acredite haber tenido conocimiento.

Tres.- Disposición derogatoria única.

Se deroga la ley XLVI del título II de la Partida III, reguladora de la acción de jactancia. Asimismo, se consideran derogadas, conforme al apartado segundo del artículo 2 del Código Civil, cuantas normas se opongan o sean incompatibles con lo dispuesto en la presente Ley. 


\section{BIBLIOGRAFIA}

ALBORNOZ VÁSQUEZ, M. E. (2007) El mandato del silencio perpetuo. Existencia, escritura y olvidos de conflictos cotidianos. Chile 1720-1840. Justicia Poder y sociedad: recorridos históricos Chile siglos XVIII-XXI. Editorial Universidad Diego Portales. Santiago de Chile.

ALFONSO X EL SABIO (2018) Fuero Real Boletín Oficial del Estado.

BARONA VILAR, S. (1999) Tutela civil y penal de la publicidad. Editorial Tirant lo Blanch. Valencia.

BECEÑA Y GONZÁLEZ, F. (1928) Magistratura y Justicia. Notas para el estudio de los problemas fundamentales de la organización judicial Victoriano Suárez.

CALDERÓN CUADRADO, M. P. (2015) Derechos, proceso y crisis de la justicia. Revista General de Derecho Procesal no 37. Madrid

CALONGE MATELLANES, A. (2002). La acción de Jactancia. Estudios de derecho romano en memoria de Benito María Reimundo Yanes. Caja Duero, Asociación Iberoamericana de Derecho Romano, Salamanca.

CENDOJ (Centro de Documentación Judicial) Consejo General del Poder Judicial. http://www.poderjudicial.es/search/indexAN.jsp.

CORBELLA Y PASCUAL, A. (1910) Voz jactancia en Enciclopedia Jurídica Española. Seix. Tomo XIX Barcelona.

CHIOVENDA, G. (1933) Azioni e sentenze di mero accertamento. Rivista di Diritto Processuale Civile, vol. 10. $1^{\text {a }}$ parte.

DE CASTRO Y BRAVO, F. (1986) Compendio de Derecho Civil. Parte General II.

DE COVARRUBIAS Y LEYVA, D. (1762) Opera omnia. Editado Genevae: sumptibus Fratres de Tournes.

DE HINOJOSA, J. (1948) Alrededor de la acción de jactancia. Revista de Derecho Privado. Editorial Reus. Madrid. Tomo XXXII.

DE LA COLINA, S. (1915) Derecho y legislación procesal. Materia Civil y comercial. Librería Nacional. Buenos Aires. Tomo I segunda edición.

DE MOLINA Y MORALES, L. (1573) De Hispanorum primogeniis. Andreas de Angulo.

DORAL GARCÍA DE PAZOS, J.A. (2002) La hibernada acción de jactancia y el problema del silencio. Estudios jurídicos en homenaje al profesor Luis Díez-Picazo. Coordinado por Antonio Cabanillas Sánchez. Semblanzas. Derecho Civil. Parte General.

ESCRICHE, J. (1875) Diccionario razonado de legislación y jurisprudencia nueva edición reformada y considerablemente aumentada por don José Vicente y Caravantes y don León Galindo y de Vera. Imprenta de Eduardo Cuesta. Madrid. Tomo III.

FAIRÉN GUILLÉN, V. (1998) La acción de jactancia como forma de tutela anticipada, Revista de derecho procesal Número 2.

.(1999) La acción de jactancia y su pasado y futuro. Anales de la Real Academia de Jurisprudencia y Legislación $n^{\circ}$ 29. Madrid.

FANJUL VICUÑA, J. I. (1996) La acción de jactancia. Estudios sobre Derecho Procesal Volumen I Obra coordinada por Ignacio Díez-Picazo Giménez y Julián Martínez -Simancas. Sanchez. Editorial Central Hispano SOPEC. Madrid. 
FERNÁNDEZ DE SANTAELLA, R. (1789) Vocabularium: seu lexicon ecclesiasticum, latino-hispanicum. Madrid.

FRAGA IRIBARNE, M. (1951) La acción meramente declarativa. Instituto Editorial Reus. Madrid.

GALANTE, V. (1910) Diritto processuale civile, "Parte genérale”, Nápoles.

GARCÍA SÁNCHEZ J. (2002) La acción de jactancia, una institución fundada en la normativa romana postclásica, aplicada en la práctica procesal canónica hispana de la Edad Moderna. Estudios jurídicos "in memoriam" del profesor Alfredo Calonge coordinado por Justo García Sánchez, Pelayo de la Rosa Díaz, Armando José Torrent Ruiz.

GÓMEZ, A. (1777) Compendio de los comentarios extendidos por el maestro Antonio Gomez a las ochenta y tres leyes de Toro. Imprenta y librería de Don Manuel Martin. Madrid. Biblioteca digital de Castilla y León.

GUÍAS JURÍDICAS WOLTERS KLUVER “La acción de Jactancia”. http://guiasjuridicas.wolterskluwer.es/.

GUTIÉRREZ GOÑI, L. (2002) Algunas cuestiones procesales en los pronunciamientos judiciales sobre la acción de jactancia. Revista Doctrinal Aranzadi Civil-Mercantil no 15/2002. Cizur Menor.

JUSTINIANO (1975) El Digesto. Traducción de Álvaro D’Ors, Hernández Tejero, Fuenteseca Díaz, M. García Garrido y J. Burillo. Editorial Aranzadi, Pamplona.

LLUÍS Y NAVAS, J. (2003) Las acciones laborales declarativas y de jactancia. Revista técnico laboral Madrid. Número 98.

MALAVER, A. M. (1944) Acción de jactancia y acción declarativa: legislación, doctrina, jurisprudencia. Editorial Depalma. Buenos Aires.

MANRESA Y NAVARRO, J.M., MIQUEL, I. y REUS, J. (1856) Ley de Enjuiciamiento Civil Comentada y Explicada. Imprenta de la Revista de Legislación. Madrid. Tomo II.

MARIÑO PARDO, F. M. (2015). Código Civil Parte General Tema 2 La codificación civil en España. Temario de oposiciones a Notaria en https://www.franciscomarinopardo.es/mis-temas/32-civil-parte-general-temas-1-a10?layout $=$.

MARTÍNEZ MOSCOSO, A. (2009) La Libertad de expresión en la nueva sociedad de la información. Perspectivas y conflictos entre derechos. Fundación Carolina. Cuenca (Ecuador).

MAYNAR BARNOLAS, M. (1944). De mi clínica. Acción de Jactancia. Revista General de Legislación y Jurisprudencia. Editorial Reus. Madrid.

MOMMSEN, T. (1976) Derecho Penal Romano (Traducción del alemán por Dorado) editorial Tennis, Bogotá.

ORTIZ DE ZÚÑIGA, M. (1870) Práctica general forense. Volumen I. Imprenta de Don José Rodríguez Calvario. Madrid.

OSORIO M. (2004) Diccionario de Ciencias Jurídicas, Políticas y Sociales. Editorial Heliasta. Buenos Aires.

PÉREZ Y LÓPEZ, A.X. (1796) Teatro de la legislación universal de España e Indias, por orden cronológico de sus cuerpos, y decisiones no recopiladas y alfabético de sus títulos y principales materias. Imprenta de Ramón Ruiz. Madrid. Tomo X

PRIETO-CASTRO FERRÁNDIZ, L. (1932) La acción declarativa (un estudio de historia, doctrina y legislación procesales. Revista General de Legislación y Jurisprudencia $\mathrm{n}^{\circ}$ 161, Madrid. 
PUIG BRUTAU, J. (1994) Fundamentos de Derecho Civil. Editorial Bosch Tomo III. Barcelona.

SANPONTS Y BARBA, I., MARTÍ DE EIXALA, R. y FERRA Y SUBIRANA, J. (1844) Las siete partidas del rey Don Alfonso el IX, con las variantes de más interés, y con la glosa del lic. Gregorio López del Consejo Real de Indias de S. M., vertida al castellano y estensamente adicionada con nuevas notas y comentarios y unas tablas sinópticas comparativas, sobre la legislación española, antigua y moderna, hasta su actual estado. Imprenta de Antonio Bergnes. Tomo II Barcelona.

SENTÍS MELENDO, S. (1943) El juicio de Jactancia (Ensayo de sistematización bibliográfica y jurisprudencial). Revista de Derecho Procesal. Tomo II. Buenos Aires.

SERRA RUIZ, R.(1969) Honor, honra e injuria en el derecho medieval español. Universidad de Murcia.

SUAREZ, R. (1588) "Excellentissimae allegationes et consilia quaedam singularia”. Editorial Diego Fernandez de Córdoba. Salamanca.

TAPIA FERNÁNDEZ, I. .(1984) Ejecución de sentencias de dar, hacer y no hacer. Universidad de las Islas Baleares. Facultad de Derecho.

(1984) Las condenas no pecuniarias. Editorial Universidad de las Islas Baleares. Facultad de Derecho. Mallorca.

TORO MELO, D. y ECHEVERRÍA Y REYES, A. (1902) Código de Procedimiento Civil anotado. Imprenta, litografía y encuadernación Barcelona. Santiago de Chile.

VALABRÈGUE, M. E. (1888) De la loi Diffamari, ou de l'action de jactancie, en droit romain et en droit français. Revue de Legislatión et Jurisprudence, XXXVII, anné, nouvelle série, t. XVII París. 